\title{
Institutional Developments in the Globalization of Securities and Futures Markets
}

INANCIAL TRANSACTIONS such as the buy. ing and selling of securities, commodities, foreign exchange and bonds, have increasingly involved individuals and firms from different countries. For example, a Japanese resident might purchase U.S. dollars with Japanese yen (a foreign exchange transaction) to buy shares of IBM on the New York Stock Exchange (a securities transactionl. To accommodate such transactions, futures and securities exchanges have expanded the services they offer their users, adding numerous financial instruments, engaging in cooperative efforts across exchanges and introducing computer-based technologies.

The globalization of world markets provides significant benefits, including greater opportunities for investors to diversify risk, and access to broader markets for demanders of funds. International trading in financial instruments, however, does pose risks, some of which can be mitigated by coordination between global financial markets.

This paper describes recent institutional developments in the globalization of financial mar. kets and discusses the advantages and disadvantages of these innovations. The paper opens with a brief overview of the various transna- tional developments that are occurring in world securities and commodities markets. It then addresses both the benefits of expanding financial markets and the costs that accompany the move. Risk factors and standardization of procedures are highlighted as issues of concern as financial centers globalize. The paper closes with a discussion of the Group of Thirty proposal for the coordination of clearing and settlement in world securities markets.

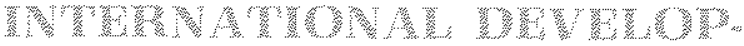 MW

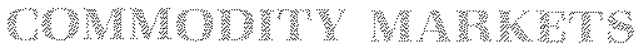

The trend toward internationalization of financial markets can be illustrated by highlighting the rapid increases in transactions in a few markets. For example, cross-country activity, when measured as the volume of foreign trans. actions in securities of U.S. firms (aggregate purchases and sales), grew from $\$ 75.3$ billion in 1980 to $\$ 361.4$ billion in $1990^{1}$ Similarly, U.S. transactions in securities of foreign firms (aggregate purchases and sales) grew from $\$ 17.85$ billion to $\$ 253.4$ billion between 1980 and $1990 .{ }^{2}$ In futures and options markets, 20 new exchanges 
were established worldwide between 1985 and 1989 , bringing the total to $72 .^{3}$ Likewise, nearly 40 million futures and options contracts were traded worldwide in 1988, an increase of approximately 186 percent since 1983.4 Eurodollar interest rate futures saw an especially large change, increasing almost 70 percent annually between 1983 and $1988^{5}$

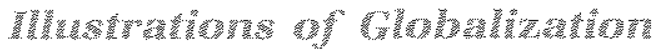

The globalization of financial and commodity markets involves numerous activities and institu. tional developments that facilitate access to foreign markets, whether by a trader or a security. One of these activities is the cross-listing of securities in several countries. Cross-listing simply means, for example, that a firm in the United States lists its stocks on a London exchange. In 1990, the International Stock Exchange (ISE) of London had one of the highest percentages (23 percent) of foreign company stock listings. ${ }^{6}$

Another trend is cross-country hedging and portfolio diversification. A U.S. trader, for example, can diversify a portfolio composed of U.S. stocks by buying stocks of a U.K. firm in London through a London broker. Globalization can also mean holding membership in another country's exchanges. For example, after "The Big Bang" of 1986 in London, many U.S. securities firms and banks applied to buy seats on London exchanges. $^{7}$

A third trend in the internationalization of financial markets is called "passing the book," whereby control of trading is passed between traders at exchanges around the globe. This enables 24-hour trading of a financial instrument. An example of this would be a U.S. investment firm trading from New York during U.S. and Japanese hours and from its London desk during U.K. hours. The more common practice of pass-

3Baer, Evanoff and Pavel (1991), p. 11

slbid.

${ }^{5}$ Eurodollar deposits are dollar-denominated deposits out* side the United States. Eurodollar interest rate futures contracts are futures contracts on the interest rates on these deposits. The figures are from Baer, Evanoff and Pavel (1991), p. 11 .

${ }^{6}$ For the New York Stock Exchange, the figure was 3.7 percent. U.S. Congress, Office of Technology Assessment (1990), p. 29

7The Big Bang was a deregulation effort for British tinancial markets which began on October 27, 1986. Examples of changes to the London equity markets are the end of fixed commission rates; barriers between order-taking brokers and risk-taking market makers were broken down; and, the self-regulating Securities and Investment Board (SIB) was ing the position book between time zones is actually to transfer the handling instructions between traders. An example is a New York currency trader who instructs the trader at his Singapore office to track the price of a currency during evening hours in New York. When the market reaches a particular price, the singapore trader will buy or sell, depending on instructions from New York.

One trend that does not involve actual trading is the underwriting of corporate securities through offices outside the home country. An underwriter is a firm that buys an issue of securities from a company, then resells it to investors. For the company issuing the securities, underwriting provides a guarantee that a certain amount of money will be derived from the sale of the securities that can be used for capital expenditure. A large stock issue may have underwriters from several countries, for example, to compensate for a country whose capital market does not have the depth to handle large securities offerings. ${ }^{B}$ The distribution of underwriters across several countries provides the issuing firm with a wider access to funding. Investors, on the other hand, obtain a broader selection of securities.

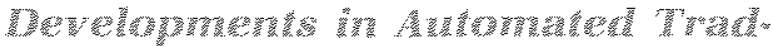

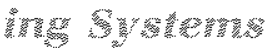

More recently, the development of automated trading has received substantial attention. Automated or electronic trading systems allow agents to make trades via computer, without the "open outcry" or pit auction system. ${ }^{10}$ Interestingly, the development of much of the current automation is an extension of technological innova tions originally developed for domestic markets. It is clear, however, that this automation has af-

established. The SIB is a non-governmental version of the Securities and Exchange Commission (SEC) in the United States. Khoury (1990), p. 129.

Depth means that there are enough buyers and sellers in a market that a large transaction will not affect the price.

9An example is the privatization of French companies in 1986, where the value of these newly privatized companies was approximately $\$ 30$ billion, but the total value of fistings on the Paris Bourse was only about $\$ 80$ billon. U.S. Congress, Office of Technology Assessment (1990), p. 34.

ropen outcry occurs on an organized exchange when ord. ers between buyers and sellers are traded between third parties in anonymity. The buyer/seller enters into a conw tract with the exchange or its representative clearinghouse. 
fected the globalization of financial markets considerably.

The National Association of Securities Dealers Automated Quotations (Nasdaq) was one of the earliest developments in financial market computerization, beginning in 1971. Nasdaq provides computer listings of price information for several thousand companies. By 1982, the National Association of Securities Dealers (NASD) had produced the National Market System, which provided investors with information as sales were completed, and by 1991, had developed the Private Offerings, Resales, and Trading through Automated Linkages (PORTAL) system. ${ }^{13}$ From a computer terminal, PORTAL enables users to trade in unregistered domestic and foreign debt and equity securities. ${ }^{12}$

Nasdaq has established computer telephone linkage as well as automated trade execution and international clearing and settlement with the International Stock Exchange of London and the Stock Exchange of Singapore. Nasdaq has since become a significant market for the listing of foreign securities, trading approximately $\$ 6$ billion in foreign securities as of 1991, up from the $\$ 2.6$ billion in $1985 .^{13}$ Thus, Nasdaq provides the cross-listing of securities, together with the rapid trade execution of an automated system.

The growth of international trading has also affected futures and options exchanges in the United States. The fact that traders could access instruments and overseas markets after normal U.S. trading hours had ended, provided a motivation for many of the extended-hour and 24-hour trading initiatives (see shaded insert for examples of extended trading hours and table 1 for automated trading systems).

A significant portion of U.S. financial instruments, futures and options is traded at exchanges throughout the world. That is, foreigners do not have to use the Chicago Mercantile Exchange to trade Eurodollar contracts, a CME staple. For example, in 1989, a third of the trade in contracts offered by the CME originated outside of North America. ${ }^{\text {t4 }}$ In 1989, 10 percent of the CME's daily volume was transacted overnight in an overseas exchange while the CME was closed. ${ }^{15}$ Furthermore, in 1985, the CME and Chicago Board of Trade together accounted for 83 percent of all futures volume. By 1990, the figure had fallen to 55 percent. ${ }^{16}$ The attempt to regain market share instigated such CME expansions as extended trading hours and automated trading systems.

Perhaps the most ambitious project in automated trading is Globex, an attempt to create a 24-hour trading market originally proposed in 1987 by the CME. ${ }^{17}$ Globex is an electronic trade execution system whereby traders enter buy and sell orders that are matched automatically according to price and time priority. ${ }^{18}$ Originating as a strictly off-hours trading system, the purpose of Globex is to enable continued active trading beyond the CME's regular trading hours. The CME intends to use Globex to access markets after its own close of business and regain some of the market share lost to foreign exchanges.

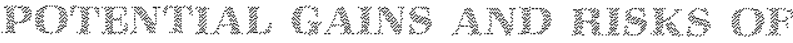

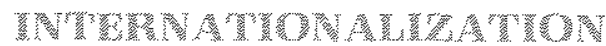

The significant changes accompanying the internationalization of fínancial trading systems allow for the realization of substantial gains; at the same time, globalization also exacerbates the risks already present in financial trading. The most significant of these gains and risks are described below.

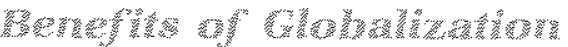

One of the most important areas of progress is the speed with which information is processed and disseminated to market participants. Increased flow of market data provides greater

\footnotetext{
1PORTAL uses a book entry settlement system with no physical delivery, eliminating the problem of unmatched trades. PORTAL is currently the only fully automated clearing and settlement system in the United States. Clearing and settlement issues, book entry and matching trades will be discussed in more detail later in the text.

12unregistered securities are not registered with the Securities and Exchange Commission (SEC). They are issued in a limited volume or by small companies.

13See Nasdaq (1991), p. 16, for the 1991 figure, and NASD (1991), p. 15, for the 1985 figure.

14Hansell (1989), p. 187
}

15ibid.

${ }^{16}$ Chester-Marsh (1991), p. 33.

tThe Chicago Board of Trade has since become a patticipant with the CME in the Globex project.

18For detailed reading on automated trading systems, see Domowitz (1990). 


\section{"After-Hours" Trading}

The following is a listing of some of the developments in trading after regular operating hours.

\section{New York Stock Exchange}

Has two after hours trading sessions, begin ning June 13,1991 . One 45 -minute, ordermatching session and a one-hour and-15:min. ute session for crossing baskets of stocks.

\section{American Stock Exchange}

Plans for an after-hours session between $4.15 \mathrm{pm}$ and $5 \mathrm{p} \mathrm{m}$. Where buyers and sellers can trade at regular session's closing price Curfently, talks with Reuters Holdings Plic, the Chicago Board Options Exchange and the Cincinnati Stoek Exchange for a global after-hours trading system for stocks and their options and denvatives sueh as stock-index wamants.

\section{Nasdaq}

Has filed with the SEC to start trading on Nasdaq International at 3.30 a.m. EDT.

\section{Midwest Stock Exchange}

Will not have its own after hours session, but will fill customer onders based on afterhours activity on the New York Stock Ex. change.

\section{Pacific Stock Exchange}

Has filed plans with the SEC to extend trading in listed stocks in a regular auction mar. ket lasting until $4: 50 \mathrm{pm}$. EDT Currently, PSE closes at 4:30 p m. EDT. Will mateh buy and sell orders in a 5 p.m. EDT session at the NYSE closing price.

\section{Philadelphia Stock Exchange}

Trades currency options and futures for 20.5 hours a day. Has filed plans with the SEC for an after hours order natching sys: tem similar to the Big Beard Alse plans to fill customer orders based on after hours activity on the Big Board.

\section{Boston Stock Exchange}

Will not have its own session, but will fill customer orders based on after hours activity on the Big Board.

\section{Chicago Board Options Exchange}

Has no current plans to trade stock options. before of after normal trading hours. Involved with Ames in electronic system.

\section{Instinet}

An electronic trading systen owned by Reuters Holdings operates up to 16 lours a day.

'PBig Board Afterthours Traditg' (1991)

accessibility to foreign markets. In turn, the larger the number of participants using a market, the greater the liquidity of the market and, thus, its desirability for investors. ${ }^{19}$

The level of market activity and the transmission of data on prices, market supply and demand conditions are a few examples of informa. tion relevant to traders. Yet, this information technology has less to do with improving the effieiency of forecasting techniques than it does to shaving seconds off the receipt of up-to-the- minute market events. Information like the announcement of a commodity quota or a corporate merger provides the impetus for the rapid decision-making that characterizes financial trading.

Access to foreign stocks provides investors with opportunities for diversification; investors need information about the foreign firm (for example, its financial stability or successful management), however, in order to make an investment decision. The rapid rise of information technolo-

19Liquidity is the depth of the market (for example, securities or futures) and its ability to absorb sudden shifts in supply and demand without excessive price fluctuation. 
gy increases the familiarity of foreign corporations and their operations. This spread of information reduces one of the traditional obstacles to foreign investment and opens up both savings and investment opportunities for firms and individuals. The payoff is a more efficient allocation of capital and, thus, a stimulus to production and real output.

Likewise, the advent of almost immediate transfer of information around the globe reduces the informational discrepancies between market participants. Arbitrageurs, of course, attempt to profit from price discrepancies. The more people have access to the same information, however, the more likely price discrepancies will be spot. ted and acted upon. The divergence of prices from their no-arbitrage relationship (which provides profit potentials), will be quickly arbitraged away as both the quantity and speed of information transfer is enhanced. ${ }^{20}$

Another benefit of internationalization is access to markets otherwise inaccessible. As mentioned earlier, the Chicago Mercantile Exchange will be accessible after regular trading hours through Globex. Not only will U.S. traders now be able to operate after U.S. trading hours, but foreign traders can also use Globex to operate during their own regular trading hours. New markets enable investors to introduce diversity into their portfolios in both the type of instrument and the country from which it is issued. Just as computerized systems, such as Globex, facilitate diversification and accessibility, so too can other methods, such as cross-exchange listings and cross-memberships.

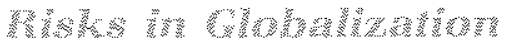

Trading in financial assets, whether done domestically or across national boundaries, involves risk. Some of these risks are more important in an international setting than a strictly domestic setting. They occur primarily at various stages of the clearing and settlement process. Unlike risks commonly associated with price uncertainty, the risks in clearing and settlement procedures involve uncertainty about the timely payment of funds and the transfer of assets in financial trades.
An example of a typical securities transaction can provide a clear illustration. Once a securities trade is executed, the member firms involved submit the trade information for confirmation to the clearing agent. The trade is then compared and matched by computer for accuracy and the information on the trade is sent to the relevant members on either the day of the trade or the day after. If both parties concur with the conditions of the trade, the trade is ready for settlement. At present, settlement in securities occurs five days after the trade in the United States.

Using this example, the next section will briefly discuss the concepts and institutions in clearing and settlement procedures before introducing the specific risks of globalization.

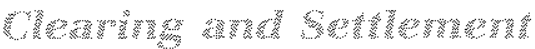

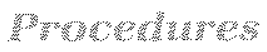

"Clearing" a trade involves the confirmation of the type and quantity of the financial instrument being traded, the transaction date and price, and the identification of the buyer and seller. "Settlement" means the fulfillment of the obligations of the transaction. In equities and bonds, for example, settlement means payment to the seller and delivery of the security certificate or transfer of ownership to the buyer.

The clearing and settlement process depends on the institutions that facilitate transactions. Commodities and securities exchanges provide the facilities for traders to conduct their business, establish and enforce trading rules, collect and distribute market and economic information about prices, and provide an institutional framework for arbitrating and settling disputes.

Another institution-the clearinghousecompares trades between parties and can remove risk from the settlement process. ${ }^{21} \mathrm{~A}$ clearinghouse places itself between the buyer and seller, ensuring that the buyer receives the instrument purchased and the seller receives payment. That is, by becoming the counterparty to all trades, the clearinghouse guarantees every trade. Each participant has a net obligation with the clearinghouse to buy or sell the security

\footnotetext{
${ }^{20} \mathrm{An}$ example of a no-arbitrage condition is that the difference between the cash and futures price of a storable commodity, at any point in time, should reflect carrying costs of storing the commodity until maturity. If the price differential exceeds carrying costs, then there exists an in"
}

centive to enter the market, that is, to buy today and seil at the higher futures price.

21Trade comparison involves confirming and matching the terms of the trade to ensure accuracy. 


\section{Table 1}

\section{Automated Trading Systems}

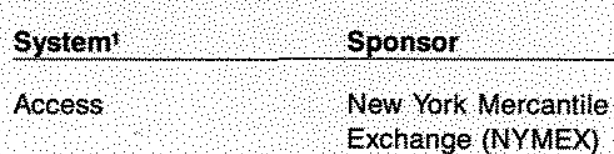

Automated Pit Trading (APT)

\section{ESV (Electronic Joint Venture)}

Euroquote
London Internationa Financial Futures Exchange (LIFFE)

Collaboration between First Boston, Goldman Sachs, Morgan Staniey. Salomon Brothers, Shearson Lehman and Citbank

European Conmunity (EC) nationa stock exchanges

Chicago Mercantile Exchange (CME) feuters and Chicago Board of Trade (CBOH)
Purpose

Computertzed soreen trading system to automatically match trade on a first in-tirst-out basis Allows traders to select a standing bid or offer (but are blind to the counterparty chosen).

Intended to extend rading hours to cover European. trading day its aim is to copy the life of the trading foor on to a computer screen

Trading system that allows dealers to buy and sell securities electronically using volce activated computer technology Also provides price and analyic services.

A European wide share trading system Wil combine price information from $2 \mathrm{EC}$ exchanges into an electronic teed tor subscribers. Eventually, may become a full trading system and integrate Euroquote with a set: tlement system to decrease the cost and difficulties of settling cross-country transactions. (This proposal has since been aban doned by the chaimen of Eu rope's national stock exchanges.)

An automated trading system with anonymous buy and sell orders that are matched by price and time (see text for detalls)
Instruments

Energy futures and tuturesoptions for crude oil heating oll, gesoline, propane and natural gas.

FTSE 100 index futures and most of LIFEE's main coniracts.

Currently restricted to Treasury bills and notes with maturity of less than three years Once established, it expects to extend coverage to all maturities.

EC stocks

Traded instruments will be introduced in three separate waves 1$)$ financial futures and options, eg, Eurodollar futures, futures and options on Eurodollar currenciesDeutschemark, yen, pound sterling Canadian and Australlan dollars, Swiss tranc. LIBOR, and US Treasury bond and note futtres and options, 2) equity related products and 3 ) agriculture related futures. 


\section{Table 1 (continued)}

\section{Automated Trading Systems}

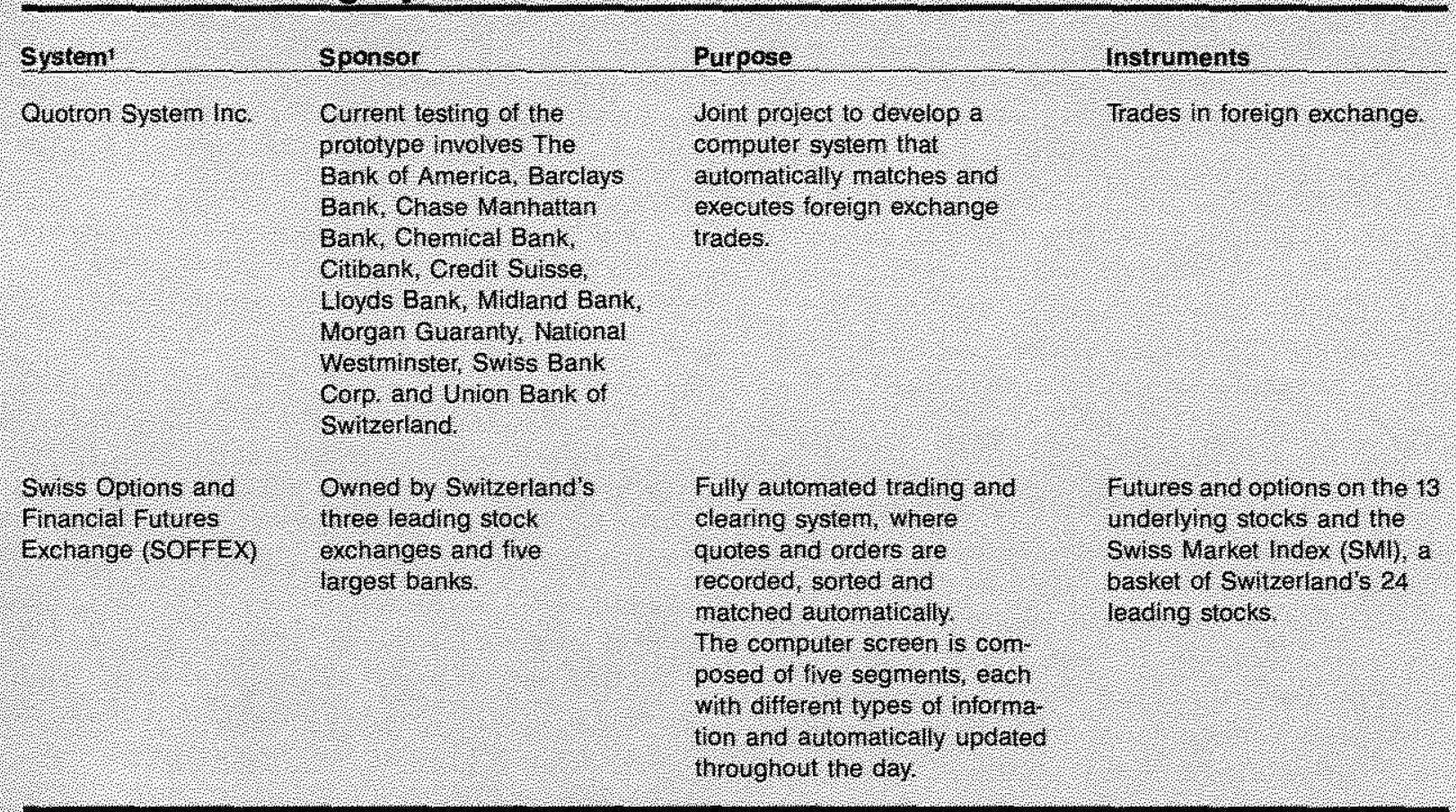

TOF these systens ony LFFES APT systen and SOFFEX are currenty in Gepation.

NotE, for a nore extensive survey or automated systems, see peler A Ablen, Gobalzation of Stoct, Futunes, and Options Markets, Federal Reserve Bank of Allanta Economic Reviov (JillAugust 1991 )

based on her net position with other participants in the clearinghouse.

A third institution - the depository-is an or. ganization (not necessarily part of an exchange) that holds stocks and bonds for safekeeping on behalf of their owners. It has a computerized accounting system to record and transfer ownership of securities between participants by integrating a book-entry system with a money transfer system. ${ }^{22}$

The procedures for clearing and settlement vary across countries. At present, there are three common methods of clearing and settlement. Each involves various combinations of the three central institutions involved in futures and securities markets.
The first model is exemplified by the United Kingdom's equities market. In this model, there is neither a central depository nor a separate clearinghouse. Instead, the stock exchange itself is responsible for trade matching and confirmation as well as providing a location for the delivery and receipt of securities and payments between traders. ${ }^{23}$

The second model, exemplified by Germany ${ }^{7}$ Deutscher Kassenverein depository system, has no independent clearinghouse, but does have a centralized depository and a stock exchange that provides the matching and confirmation of transactions. Once matched and confirmed, the trade information is sent to the depository for settlement. ${ }^{24}$
22A book-entry system means a credit or debit to a cus-
tomer's account will transter securities between buyer and
seller. A money transter system transfers the funds between the parties to the trade, such as a wire transfer.

\footnotetext{
23U.S. Congress, Office of Technology Assessment (1990), p. 58 .

24lbid.
} 
The third model, as seen in the U.S. equities market, contains all three institutions: a stock market, a central depository and an independent clearinghouse. For example, the National Securities Clearing Corporation (NSCC), which processes 95 percent of all equities trades in the United States, is jointly owned by the New York Stock Exchange, the American Stock Exchange, and NASD ${ }^{25}$ The majority of the securities for NSCC members, in turn, are held by the Depository Trust Company. The stock market and clearinghouse together match and confirm transactions. The clearinghouse also places itself between counterparties to trades, then passes trade information to the depository. ${ }^{26}$

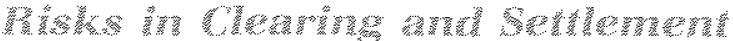

Credit (or counterparty) risk occurs when one side of the transaction does not settle in full, either when due or on a later date. The exis. tence of counterparty risk, which is of minimal significance in many U.S. markets because of a clearinghouse, can be critical in an international transaction. The clearinghouse, generally well capitalized, guarantees that all trades will be hon" nored. In many international transactions, however, no clearinghouse exists. Thus, a trader lacks information about the counterparty's reliability. Varying regulations on foreign trading may make it even more difficult to ascertain the safeguards available to a trader in that market.

Closely related to credit risk is liquidity risk, which is the risk that trades will not be settled at the appointed time, but at some undetermined time thereafter. ${ }^{27}$ At settlement, counterparties are exposed to both credit and liquidity risks. Liquidity risk occurs because settlement may not occur on the specified date; credit risk occurs because the other party may not deliver at all. Thus, at settlement, the parties may not know whether the problem will be one of liquidity or credit. The settlement of international trades can exacerbate the problem of simultaneously exchanging securities for payment because of time zone differences. ${ }^{28}$

Another risk, replacement cost risk, occurs when the price of the security changes between trade and settlement. When one party has defaulted and the price of the instrument changes, then one of the parties involved would be adversely affected by the price change and suffer a loss in replacing the transaction. In foreign markets, the potential for adverse changes in the exchange rate can exacerbate this risk.

Operational risk occurs because of the possible failure of computer systems, telecommunications or institutionalized procedures during trading. Given the heavy reliance on technology in accessing financial markets abroad, this issue is extremely important in determining the success or failure of new trading systems. The precautions taken by the CME for its Globex system-an important part of its initial proposal to the Commodity Futures Trading Commission, a government regulator of futures exchanges-are a good example of this. ${ }^{29}$

Yet another risk, especially worrisome to regulators, is systemic risk. Systemic risk occurs when credit risks stemming from operational or financial problems result in agents exiting the market, which, in turn, threatens the industry. The inability of one financial institution to make its payments can cause other participants to be unable to meet their financial obligations in a timely manner. In the banking sector, this is typified as a run from deposits to currency. In futures and options, it occurs when agents no longer trade through standard channels tike an exchange. For example, if members of an exchange begin trading elsewhere, the financial stability of the exchange is threatened as members withdraw their financial collateral. ${ }^{\text {su }}$
25U.S. Congress, Office of Technology Assessment (1990), p. 81 .

${ }_{26}^{26}$ or related readings on clearance and settlement systems, see the monographs prepared by the Payment System Studies Staff of the Federal Reserve Bank of New York in the references to this paper.

${ }^{27} \mathrm{~A}$ temporary inability to convert assets into cash is often associated with liquidity isk while bankruptcy of a counterparty is associated with credit risk. For a more detailed description, see Federal Reserve Bank of New York (February 1989).

${ }^{29}$ For further reading on market risks, see Baer and Evanoff (1990).

\footnotetext{
${ }^{29}$ Examples of $\mathrm{CME}$ precautions include measures to prevent unauthorized individuals from accessing the system, such as four different identification codes; termination of a computer operator's session if nonstandard instructions are entered; and, in the failure of the central computer, recovery would involve automatic switchover to a back-up mainframe, taking approximately $60-90$ seconds. See CFTC (1989), pp. 125-32.

30For further reading on systemic risks, see OECD (1991).
} 


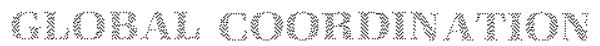

The October 1987 stock market crash, with worldwide repercussions, revealed weaknesses in the clearing and settlement system. Many feared that the default of a major market player could threaten the financial systems of many countries. This prompted world financial leaders to work toward global coordination. The clearing and settlement of trades was considered one of the most crucial aspects of this coordination

In 1989, the Group of Thirty issued a report, Clearing and Settlement Systems in the World's Securities Markets.31 Based on its examination, five critical deficiencies in the clearing and set. tlement systems across countries were iden* tified:

[1] Absence of compatible trade confirmation and matching systems for both domestic and international trades;

[2] Varying settlement periods across the different markets;

[3] Absence of delivery versus payment in some markets;

[4] Absence of standardized trade guarantees;

[5] Absence of book entry processing for settlement of securities transactions in several markets.

\section{算W}

Trade confirmation and matching, also known as trade comparison, is the process of confirming and matching the terms of a trade to ensure accuracy (for example, the issue, price, quantity and counterparties) and is usually done by a clearinghouse (although sometimes by an exchange or by the parties themselves, in the forward foreign exchange market). If not confirmed and matched, a chain reaction of failed trades is possible as subsequent trades are made on the assumption that earlier trades will be successfully completed.

Rapid trade comparison shortens the amount of time between when the trade is made and when it is successfully matched. This reduces credit risk by reducing the amount of time an agent has to opt for defaulting on a trade. In the international context, delays of hours in a domestic market may result in a delay of days for international trades. Requiring all investors to obtain membership in a trade comparison system and achieving a compatible system across international markets can reduce the delays and credit risks involved in diverse systems.

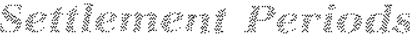

The second deficiency is unequal settement periods, which can increase settlement risk and potential default. Settlement risk occurs when there are gaps in the timing of payments and receipts on settlement date. ${ }^{32}$ The harm of dif ferent settlement periods is that, as mentioned earlier, traders or investors who are active participants in the market make later trades contin. gent on the assumption of the successful settlement of earlier trades. Hence, the harm is twofold-the default of an earlier counterparty and the dependence on this trade that could jeopardize subsequent trades. As with many trade issues that require timeliness, delays in settlement can be exacerbated if spread across different trading hours and time zones.

While this is costly in a domestic market, the investment of a U.S. agent dealing in international markets can be even more costly because it is also subject to the economic conditions of foreign countries and exchange rates. Adverse changes in the exchange rate can turn a minor loss into a significant one in the presence of currency risk. Thus, for agents moving between international markets, an uncertain settlement period combined with an uncertain exchange rate can increase financial losses.

The growing volume of trades has led to a number of techniques where, to reduce the number of settlement transactions, trades are not processed one at a time. "Netting" is a system whereby transactions are aggregated, so that debit and credit positions offset each other, leaving a participant with one final position in the market of owing or being owed. Netting greatly inereases the liquidity of the market and the trader's flexibility because, rather than posting collateral for every trade, the trader is responsible only for the net settlement debit. ${ }^{33}$
${ }^{31}$ The Group of Thirty is a private sector organization that takes its membersiip from financial sectors such as exchanges, banks and investment houses.

${ }^{32}$ Settiement risk encompasses both liquidity risk and credit risk.
${ }^{33}$ Board of Governors of the Federal Reserve System and the Federal Reserve Bank of New York (1990), p. 40. 
There are three main choices for a netting system. The first is bilateral netting, whereby all trades in the same security and between the same parties to the trade are netted to one final delivery versus payment (DVP). ${ }^{34}$ For example, if Ralph sells 100 shares of British Mohair to Sam, then buys back 75 shares of British Mohair from Sam, the net position is that Ralph must deliver 25 shares to Sam. This is the narrowest of the three netting options.

The second is multilateral netting for daily netting), which, unlike bilateral netting, allows for different counterparties in the netting scheme. In this instance, all trades in the same security are netted to a final debit or credit position for each participant.

The last option is continuous net settlement, whereby all trades in a particular security are pooled by issue to a final debit or credit position for the day and any unsettled trades are carried over and offset against the next day's trades. In practice, the clearing corporation stbbstitutes as the counterparty to the trade in continuous net settlement.

The type of netting system implemented depends on the volume of the market. Establishing a multilateral or continuous net settlement system is a costly procedure, requiring a risk. sharing arrangement among members, a clearing corporation (as with continuous net settlement) and powerful computer systems to handle the volume of trades. The costs of such a system may exceed the costs of operating with only a bilateral system. This is especially true in low-volume markets where bilateral netting can be a feasible and less costly alternative. A proposal for a multilateral netting system in the high-volume foreign exchange market was examined in 1988 by members of FXNET, a bilateral netting system. ${ }^{35}$ Representatives of leading international banks, responding to FXNET's questionnaire, felt that a major benefit would be to reduce processing costs. ${ }^{36}$

This is especially relevant in markets expanding their foreign membership. If netting is desirable because it reduces the number of trades to process, it becomes even more so as markets service no longer just domestic, but a growing number of foreign clients. In the FXNET questionnaire, respondents stated that, "Cross-border aspects of multilateral netting should be considered early in the process, as they will be more important than with bilateral netting." ${ }^{\prime 37}$ With the addition of cross-border traders increasing the transactions volume a market handles, a netting system would simplify the repeated payments that would be introduced.

Whichever netting system is chosen, the desirable settlement time frame is a rolling settlement system. In such a system, trades settle on all business days of the week, scheduled the same number of days after the trade. ${ }^{38}$ Thus, the presence of a standardized settlement period and a netting system is a crucial aspect to moving between international markets with security of settlement.

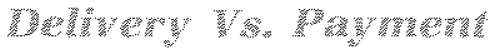

The third finding by the Group of Thirty is the absence of delivery versus payment (DVP) in some markets. DVP is a two-sided payment system that simultaneously debits or credits the cash account of one member and makes the corresponding entry on the securities side of the transaction. This reduces the settlement risk that occurs when there is a discrepancy between the timing of payments and receipts on settlement date.

The Group of Thirty, arguing the need for prompt two-sided payments, has recommended interim procedures: risk can be reduced by delivering securities only against a certified check or by employing a mechanism whereby delivery and payment are done simultaneously although through different systems. In either case, net settlement of cash and securities is completed by the end of the day.

Even without a formalized DVP, methods can be developed to minimize settlement risk by having both parties to a trade settle their accounts simultaneously. With markets in different time zones and, thus, different operating hours, allowing each side of a trade to settle at a differ-

34DVP is a payment system whereby the debits and credits $37 b i d$. of a trade are applied to the parties' accounts simultaneously.

35 For further reading on the netting of foreign exchange transactions, see Gilbert (1992).

${ }^{36}$ Minutes of FXNET Multilateral Netting Steering Committee, (1989).

38The Group of Thirty recommends the implementation of a rolling settling system by 1992 so that final settement occurs three days after the trade. 
ent time could result in a next-day payment, not one within the hours of the first settlement.

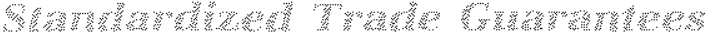

The fourth deficiency is the absence of standardized trade guarantees. A trade guarantee ensures that all compared or netted trades will be settled, based on the conditions on which they were compared, even in the event of counterparty default. To assure trade guarantees, each member of the comparison and netting systems assumes the default risk of the system.

A standard method of providing a guarantee is to establish a general clearing fund based on member contributions. When a default occurs, the losses are first extracted from the defaulting party's clearing fund contribution. If that contribution does not meet the full amount of the loss, the remander is charged against the clearing corporation's general clearing fund.

The international enviromment adds an extra facet to these guarantees. Since membership is becoming increasingly international, a major financial loss can strain the capacity of the corporation to handle the failure immediately. obtaining permission for access to additional funding, for example, could cause unnecessary delays. Thus, the maintenance of additional sources of funds, like member deposits or access to bank lines, becomes crucial in an international setting. To ensure the integrity of the corporation and, thus, the market, trade guarantees provide a measure of security and stability in the face of potential failures.

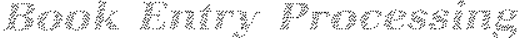

The last issue to be addressed in global coordination is the absence of book entry processing for settling securities transactions in several markets. Before addressing book entry, however, other institutions surrounding this process should be introduced.

The first of these is a central securities depository (CSD). ${ }^{39}$ The primary activity of a CSD is to immobilize and dematerialize securities so that they can be processed in the more efficient book entry method. Immobilization of

${ }^{39}$ The strict definition of a CSD requires that a country should have only one depository. In practice, however, more than one may exist. This type of system can be effective as long as there is linkage between the entities to coordinate trade information. The United States has sever. a] depositories. securities means that the physical documents (for example, share certificates) are stored at the depository, eliminating their actual move. ment when ownership changes. Dematerialization means that no physical securities with title of ownership are issued. Securities exist solely as computer records.

Transfers of certificates are done by book entry, where a simple credit and a balancing debit to customers' computerized accounts on the books of the CSD will transfer securities from one account to another. Immobilization and dematerialization replace the more risky and timeconsuming process of transferring the securities in paper form whenever a transaction is made. Transfers of stocks trade-by-trade introduce a needless complication to the clearing and settlement system, which becomes even more complicated if it involves delivering them to investors worldwide.

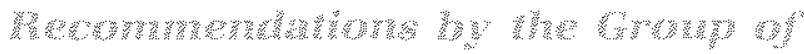 Whang}

The Group of Thirty has proposed nine recommendations found in table 2 to correct the preceding five deficiencies. The status of the Group of Thirty recommendations are listed in table 3 . This table depicts the extent to which 21 countries have made progress on these recommendations. While the United States has accomplished more than most of the countries surveyed, the fact that so many countries have not finalized these policies, and may not by 1992, has implications for the eventual timetable of global coondination.40

Currently, there is no well-defined regulatory structure for the global marketplace. While regulatory authorities exist in specific countriesfor example, the Securities and Exchange Commission has the regulatory authority, oversight and arbitration of securities disputes in the U.S. stock market-the international arena has no similar agency to govern global financial relations. In its absence, voluntary coordination of clearing and settlement systems can help reduce the risks that lead to defaults, failures and potential disputes between legal and regulatory authorities. Thus, there are potential gains if

\footnotetext{
40In addition to the Group of Thity proposal, other groups, such as the Working Group on Financial Markets have studied clearing and settement issues.
} 


\section{Table 2}

\section{Group of Thirty Recommendations}

The following are nine recommendations put forth by the Group of Thity to correct the deficiencies it finds in the cootination of clearing and settlement systems the numbers in brackets are the relevant deficiencies presented in the section, Global Coordination, that these recommendations address.

- By 1990 all compartsons of trades between direct market participants (le, brokers, brokeridealers and other exchange members) should be accomplished by $T+1$, (the first day atter the trade) [1]

- Indirect market participants (such as institutional investors of any trading countemartes that are not brokerideaters) should, by 1992 , be members of a trade comparison system that acheves positive affirmation of trade details [1]

- Each country should have an effective and fully developed central securities depository of ganized and managed to encourage the broadest possible tndustry participation (directly and ndirectly) by 1992 [3, 5$]$

- Each country should study its market volume and participation to determine whether a trade netting system would be beneficial in terms of reducing risk and promoting efficlency if a netting system would be appropriate, it should be implemented by 1992 [2]

- Delvery versus payment (DVP) should be employed as the method for settling all securites transactions. A DVP system should be in place by 1992 [3 5$]$

- Payments associated with the settlement of securities transactions and the servicing of securities portfolios should be made consistent across all nstruments and harkets by adopting the same day funds convention $[2]$

- A Rolling Settlement' system should be adopted by all markets. Final settlement should occui on T 3 by 1992 As an nterin target, tinal settlement should occur on $T+5$ by 1990 at the latest save only where it hinders the achievement of $T+3$ by 1992 [2]

- Secunttes lending and borrowing should be encouraged as a method of expediting the seftement of securites transactions Existing regulatory and taxation barriers that inhibit the practice of lending securities should be removed by 19902 (4)

- Each country should adopt the standard for securities messages developed by the Internaional Organization for Standardization $1 S O$ Standard $T 75$. In particular, countries should adopt the ISIN numbering system for securties issues as defined in the 150 standard 6166 at least for cross-border transactions. These standards should be universally applied by 1992.

Group of Thirty (March 1989)

2For information on securitles lending, see Paul $C$ Lipson, Bradiey $K$. Sabel, and Frank Keane "Securities Lending" (Federal Reserve Bank of New York, August 1989).

the clearing and settlement systems operating in domestic markets are coordinated among global financial markets.

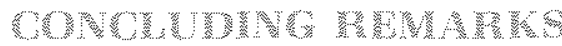

This discussion has attempted to present an overview of issues that are currently of interest in the globalization of financial markets. The linkage among international markets is of interest both to private investor's and to national governments, who desire stable domestic and international financial sectors.
International competition among financial markets is growing rapidly and has produced benefits such as new financial instruments, new markets and extended trading hours. These changes, however, are not without costs. Domestic rules and regulation are not sufficient safeguards for a system that operates in an in creasingly international environment. Financial and governmental communities are addressing the need to integrate international expansion to facilitate the continued safe and profitable growth of financial instruments and the important functions these markets serve. It is clear that much work remains. 
Table 3

\section{Current Status of the Group of Thirty's Recommendations for International Settlement-Equities}

\begin{tabular}{|c|c|c|c|c|c|c|c|c|c|}
\hline Recommendation No. & 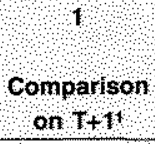 & 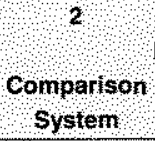 & 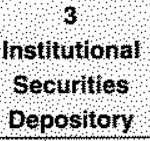 & 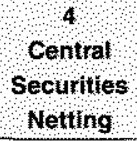 & $\begin{array}{l}\text { s } \\
\text { Delluery } \\
\text { versus } \\
\text { Payment }\end{array}$ & 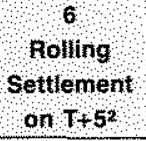 & $\begin{array}{l}\text { Same Day } \\
\text { mumds }\end{array}$ & ISOISM & 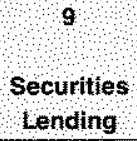 \\
\hline Australa & Yes & $\mathrm{No}$ & No & $\mathrm{No}$ & Yes & Open & $\mathrm{No}$ & No & Yes \\
\hline Austra & Yes & $\mathrm{No}$ & Yes & $\mathrm{No}$ & No & Woekly & $Y e s$ & $\mathrm{No}$ & No: \\
\hline Belglum & No & $\mathrm{No}$ & Yes & No & Yes & Fonthontly & Yes & No & Yes \\
\hline Canada & Yes & Yes & Yes & Yos & Yes & $1+5$ & $\mathrm{Yes}$ & $N o$ & Yes \\
\hline Denmark & Yes & $\mathrm{No}$ & No & No & Yes & $1+3$ & Yes & $\mathrm{No}$ & Yes \\
\hline Enand & Yos & $\mathrm{N}$ & $\mathrm{No}$ & $\mathrm{No}$ & Yes & $1+5$ & $\mathrm{No}$ & $\mathrm{No}$ & $\mathrm{No}$ \\
\hline Fance & Yes & No & $\mathrm{Yes}$ & $\mathrm{No}$ & $N o$ & Honthy & Yes & No & Yes \\
\hline Oemany & Yes & $N o$ & Yes & 10 & Yes & $1+2$ & $\mathrm{Yes}$ & $\mathrm{No}$ & 10 \\
\hline Hong Kong & $\mathrm{res}$ & $\mathrm{No}$ & No & No & Yes & 14 & No & No & $11+1 \mathrm{ed}$ \\
\hline $1 \mathrm{tal}$ & Yes & No & Yes & No & Yes & Uonthy & Yes & $\mathrm{No}$ & Ltrited \\
\hline $\mathrm{sapan}$ & Yes & $\mathrm{No}$ & No & Yes & 106 & 13 & No & $\mathrm{No}$ & Yes \\
\hline Korea & 10 & $\mathrm{No}$ & 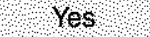 & $\mathrm{No}$ & $\mathrm{Yes}$ & 12 & $N o$ & $\mathrm{No}$ & 10 \\
\hline Nethertands & Yes & $\mathrm{No}$ & $80 s$ & Yes & Yes & 145 & 10 & No & Yes \\
\hline Nonnay & $\mathrm{Yes}$ & $\mathrm{No}$ & $\mathrm{No}$ & No & Yes & $1+6$ & Yes & No & $N 0$ \\
\hline S1moapor & yes & 10 & No & No & Xes & $1+5$ & 10 & No & 808 \\
\hline Span & Yes & No & No & No & $\mathrm{NO}$ & Weety & $\mathrm{No}$ & $\mathrm{No}$ & Lmiled \\
\hline Sweden & res & No & Yes & $\mathrm{No}$ & Yos & $1+5$ & 10 & $\mathrm{No}$ & Yes \\
\hline Swuzerland & Yes & $N o$ & $8 \mathrm{~s}$ & No & los: & $1+3$ & Yes & $\mathrm{No}$ & Yes \\
\hline Thaland & $\mathrm{yes}$ & 10 & $80 s$ & Yes & Yes & $1+4$ & Yes & $\mathrm{No}$ & No \\
\hline United Kingdom & Yes & 108 & 10 & $\mathrm{Yes}$ & No & Fonteghty & $\mathrm{No}$ & No & Llauted \\
\hline Snited States & Yes & Yes & Yes & Yes & Yes & TH5 & No & No & Yes \\
\hline
\end{tabular}

SOURCE Updated by the Oftice of Techrology Assessment, July 1990 , tron A Comparative View The oroup of Thity's Recommendations and the Curent US, National Clearance and Settlement System (Morgan Stanley 8 Co, June 1989 )

$17+1$ means the tirst day after the trade.

$2 T+5$ means five days after the trade.

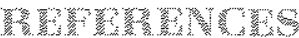

Abken, Peter A. "The Globalization of Stock, Futures, and Options Markets." Federal Reserve Bank of Atlanta Economic Review (July/August, 1991), pp. 1-22.

Baer, Merbert L., and Douglas D. Evanoff. "Payments System Risk Issues in a Global Economy." Federal Resenve Bank of Chicago Working Paper 90-12 (Augusi 1990),

Baer, Herbert L., Douglas D. Evanoff, and Christine A.Pavel "Payments System Issues in a 24-Hour Global Economy," Research in Financial Services: Public and Private Policy (vol. 3) (JAl Press, Inc., 199t).

"Big Board After-Houfs Trading May Lead to a Two-Tier Market;" Wall Street Journal, June 13, 1991.

Board of Governors of the Federal Reserve System and the Federal Reserve Bank of New York. Clearance and Settle ment in U.S. Securities Markets, Prepared for the Committee on Payment and Settlement Systems, Bank for International Settlements. (Basle, Switzeriand: December $5 m 6,1990)$.
Chester-Marsh, Caren. "Globex Countdown," Euromoney (March 1991), pp. 33-35.

Chicago Mercantile Exchange. Globex Report: An Update for the Global Trader (November 14, 1990).

Chicago Mercantile Exchange, Business Development Group. The Challenges of the 24-Hour Financial Marketplace (May 1989).

Commodity Futures Trading Commission, Division of Trading and Markets. Chicago Mercantile Exchange's Proposed Globex Trading System (February 2, 1989).

Diamond, Barbara B., and Mark P. Kollar. 24-Hour Trading: The Global Network of Futures and Options Markets (John Witey \& Sons, 1989).

Domowitz, lan. "The Mechanics of Automated Trade Execution Systems;" Journal of Financial intermediation (June 1990), pp. 167-94.

Federal Reserve Bank of New York. "An Overview of the Operations of the Options Clearing Corporation" (April 1989). 
"Clearing and Settlement Through the Board of Trade Clearing Corporation" (February 1990).

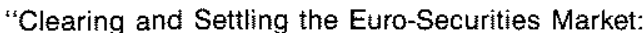
Euro-Clear and Cedel" (March 1989).

"Exchanges and Clearinghouses for Financia: Futures and Options in the United Kingdom" (March 1989).

"The Clearing House Interbank Payments System" (January 1991).

Bank for International Settlements. Report on Netting Schemes (February 1989).

FXNET Multifateral Netting Steering Conmittee, Documentation (February 1, 1989).

Gilbert, R. Alton. "Implications of Netting Arrangements for Bank Risk in Foreign Exchange Transactions," this Review (January/February 1992), pp, 3-16.

Group of Experts on Payment Systems, Bank for Internationaf Settlements (BIS). Report on Netting Schemes (Basle, Swizzerland, February 1989).

Group of Thirty. Clearance and Settlement Systems in the World's Securities Markets (New York and London, March 1989).
Hansell, Saul. "The Computer that ate Chicago," Institutional Investor (February 1989), pp. 181-88.

Khoury, Sarkis $\mathrm{J}$. The Deregulation of the World Financial Markets: Myths, Realities, and impact (Greenwood Press, Inc., 1990).

Nasdaq Stock Market, Business Development. Nasdaq: The Stock Market for the Next 100 Years (Washington, D.C., 1991).

National Association of Securities Dealers (NASD). Nasdaq Fact Book \& Company Directory (Washington. D.C., 1991)

Organization for Economic Cooperation and Development (OECD). Systemic Risks in Securities Markets (Paris: OECD Publications Service, 1991).

Soffex. Soffex Swiss Options and Financial Futures Exchange Ag, reprinted from a Supplement to Euromoney (June 1990).

U.S. Congress, Office of Technology Assessment. Trading Around the Clock: Global Securities Markets and Information Technology-Background Paper, OTA-BP-CIT-66 (Govern* ment Printing Office, July 1990).

Working Group on Financial Markets. Clearance and Settlement Reform: The Stock, Options, and Futures Markets are Still at Risk (Government Printing Office, April 1990), 